\title{
Comparison of a DNA based PCR method with conventional methods for the detection of $M$. tuberculosis in Jos, Nigeria
}

\author{
Agatha Ani ${ }^{1,2}$, Silvanis $\mathrm{Okpe}^{3}$, Maxwell Akambi ${ }^{2}$, Emeka Ejelionu ${ }^{2}$, BitrusYakubu, ${ }^{4}$ Olajide \\ Owolodun ${ }^{4}$, Peter Ekeh ${ }^{2}$ Agbaji Oche ${ }^{2}$, Dinchi Tyem ${ }^{4}$ and John Idoko ${ }^{2}$ \\ ${ }^{1}$ Department of Medical Microbiology University of Jos, Nigeria \\ ${ }^{2}$ Harvard APIN Plus Jos University Teaching Hospital, Jos, Nigeria \\ ${ }^{3}$ Department of Paediatrics, University of Jos, Nigeria \\ ${ }^{4}$ Molecular Biology Laboratory, National Veterinary Research Institute, Vom, Nigeria
}

\begin{abstract}
Background: To achieve early diagnosis and effective treatment of pulmonary tuberculosis, simple and sensitive methods that enhance the detection of Mycobacterium tuberculosis (M. tuberculosis) from clinical specimens are needed. This study compared the effectiveness and suitability of an insertion sequence (IS 6110) based polymerase chain reaction (PCR) assay with conventional methods for the detection of M. tuberculosis from clinical specimens in a resource-limited setting.

Methods: Sputa from $101 \mathrm{HIV}$-positive patients and 40 clinical specimens (sputa, gastic wash out, ascitic fluid, pleural fluid and cerebrospinal fluid) collected from children (HIV status unknown), all suspected for pulmonary tuberculosis at the Jos University Teaching Hospital, Jos, (JUTH) Nigeria, were examined by Ziehl Neelsen (ZN) smear microscopy, Lowenstein Jensen's (LJ) egg-based culture, and PCR methods for the detection of $M$. tuberculosis

Results: Mycobacteria was detected in 45/101 (44.6\%) of the specimens from the HIV-positive patients and comprised of $6 \%$ $\mathrm{ZN}^{+}$culture ${ }^{+} \mathrm{PCR}^{+}, 4 \% \mathrm{ZN}^{-}$culture ${ }^{+} \mathrm{PCR}^{-}, 16 \% \mathrm{ZN}^{-}$culture ${ }^{+} \mathrm{PCR}^{+}$and $19 \% \mathrm{ZN}^{-}$culture $\mathrm{PCR}^{+}$. Twenty-two of forty (55\%) children were positive with $0 \%$ smear microscopy; $4 / 40(10 \%)$ culture ${ }^{+} \mathrm{PCR}^{+}$; and $18 / 40(45 \%)$ culture $\mathrm{PCR}^{+}$. The sensitivity and specificity of the PCR for the HIV-positive patients were $85 \%$ and $74 \%$ respectively against $23 \%$ and $100 \%$ for ZN smear microscopy.

Conclusion: The IS6110 PCR is a rapid and sensitive method that is specific for the M. tuberculosis complex group. It is simple in our experience and increased the detection of $M$. tuberculosis from the specimens examined. We suggest its use for the detection of $M$. tuberculosis in high TB and HIV burden areas.
\end{abstract}

Keywords: tuberculosis, PCR, HIV

J Infect Dev Ctries 2009; 3(6):470-475.

Received 22 February 2009 - Accepted 24 June 2009

Copyright (c) 2009 Ani et al. This is an open-access article distributed under the Creative Commons Attribution License, which permits unrestricted use, distribution, and reproduction in any medium, provided the original work is properly cited.

\section{Introduction}

Tuberculosis continues to be a leading cause of death, especially in the developing countries where co-infection with HIV constitutes significant public health problems [1-2] In Nigeria, as in most resource-limited countries, the Ziehl Neelsen's (ZN) smear microscopy method is used in clinical laboratories for the confirmation of clinical TB. However, its limited sensitivity (detection limit: 1000 bacilli/ $\mathrm{ml}$ of sputum) and specificity (identifies only acid fast bacilli) [3] make it less dependable than other methods, especially in cases of poor sputum quality and low mycobacteria content [4-6]. The culture method is the gold standard because it is more sensitive than microscopy and highly specific [3] However, most routine laboratories do not culture for Mycobacteria tuberculosis (M. tuberculossis) due to the slow turnaround time (three to eight weeks) of the Lowenstein Jensen (LJ) method [7] or the high cost and lack of advanced technology needed for the more sensitive automated methods [2].

Nigeria is one of Africa's largest countries with a population of about 140 million people, with a TB incidence rate of 57.5 per 100,000 population, case notification rates (new and relapse) of 59.2 per 100,000, and actual sputum smear positive detection rate of $31.7 \%$ [8]. The World Health Organization (WHO) ranked Nigeria as the fourth highest in global TB burden [6]. These findings underscore the need for improved methods for laboratory diagnosis of TB in Nigeria.

Although $\mathrm{ZN}$ microscopy is cheap, rapid, and easy to perform, its limited sensitivity appears to 
compromise the program of National TB control, including directly observed treatment short course (DOTS) since only smear microscopy positive cases are eligible for DOTS enrolment [9-10]. Findings from a previous study in Jos, (North Central Region) had indicated that there is a need to review the procedures for $\mathrm{TB}$ diagnosis and treatment in Nigeria [11].

Reports on the use of PCR for the detection of M. tuberculosis in clinical specimens date over a decade [12-15]. Most of the studies, however, were performed in non-endemic western countries with only a few [16] from some endemic nations of subSaharan Africa [17]. The IS6110 sequence is specific for the $M$. tuberculosis complex ( $M$. tuberculosis, M. africanum, M. bovis, M. microti and $M$. canetti) [18]. The sequence, which undergoes several inverted repeats in the bacterial chromosome, has been cloned and used for detection and for molecular epidemiological studies of the $M$. tuberculosis complex group [16].

The present study compared the IS6110 DNA based PCR assay with smear microscopy and LJ culture for the diagnosis of pulmonary tuberculosis (PTB) using clinical specimens from HIV-positive patients and children suspected for PTB at the Jos University Teaching Hospital, Jos, Nigeria. The aim was to determine the performance and the suitability of the IS6110 PCR assay in detecting $M$. tuberculosis in clinical samples in a resource-limited setting with high TB and HIV burden.

\section{Materials and Methods}

\section{Specimens}

Sputa from 101 HIV patients comprised of 70 new, 14 follow up, 9 fail, 2 re-treatment, and 6 'relapse' (Table 1) cases, and body fluids (11 gastric washout, 10 sputa, 9 pleural fluid, 5 ascitic taps and 5 cerebro spinal fluid [CSF]) from 40 children (HIV status not known), with clinical diagnosis of PTB at the Jos University Teaching Hospital Jos, Nigeria, were examined for detection of $M$. tuberculosis by smear microscopy, LJ culture, and the IS6110 DNA based PCR. All the specimens were collected between January and December 2008.

\section{Specimen preparation}

Sputum specimens were decontaminated with equal volume cetyl pyridinum chloride (CPC) and centrifuged for sedimentation of mycobacteria. Deposits obtained after centrifugation were used to prepare smears for microscopy and inoculated onto duplicate LJ slopes. All preparations were processed according to standard methods [7,19]. Centrifuged deposits of other specimens from the children excluding sputa were processed directly without CPC treatment.

\section{DNA extraction}

Two loops of M. tuberculosis cultures or $500 \mu \mathrm{l}$ of deposits from decontaminated clinical specimens were suspended in $400 \mu \mathrm{l}$ TE buffer in $1.5 \mathrm{ml}$ microcentrifuge tubes. These were frozen at $-20^{\circ} \mathrm{C}$ for 15 minutes, heated up to $100^{\circ} \mathrm{C}$ in a water bath for five minutes, frozen again at $-20^{\circ} \mathrm{C}$ for 15 minutes, and processed for DNA extraction.

Briefly, $100 \mu \mathrm{l}$ of STEP $(1 \mathrm{ug} / \mu \mathrm{l}$ proteinase $\mathrm{K}$ in STE buffer $\mathrm{pH}$ 7.5) was added to frozen samples, mixed well, and heated at $50^{\circ} \mathrm{C}$ in a water bath for 60 minutes with occasional gentle mixing. Next, 600 $\mu 1$ phenol chloroform/isoamyl alcohol (25:24:1) (SIGMA ${ }^{\circledR)}$ was added and mixed gently for five minutes to emulsify without vortexing. The mixture was centrifuged at $12,000 \mathrm{rpm}$ for 10 minutes. The top aqueous DNA layer was transferred to a clean tube while avoiding the interface, and 0.1 volume of absolute ethanol was added, mixed by inversion to precipitate DNA, centrifuged at 1,200 rpm for 10 minutes, washed with $70 \%$ alcohol, and centrifuged again at $1,200 \mathrm{rpm}$ for 10 minutes. The supernatant was discarded and extracts were dried in a heat block at $50^{\circ} \mathrm{C}$.

Table 1. Definition of TB cases for registration on diagnosis (WHO/CDC/2003/TB.313)

\begin{tabular}{ll}
\hline TB cases & \multicolumn{1}{c}{ Definition of cases } \\
\hline New & $\begin{array}{l}\text { A patient who has never had treatment for TB or who } \\
\text { has taken anti-tuberculosis drugs for less than 1 month }\end{array}$ \\
\hline Follow-up & $\begin{array}{l}\text { A patient who has been taking anti- tuberculosis drugs } \\
\text { for two months or more }\end{array}$ \\
\hline Fail & $\begin{array}{l}\text { Patient who is sputum smear positive at } 5 \text { months or } \\
\text { later during treatment }\end{array}$ \\
\hline Re-treatment & $\begin{array}{l}\text { A patient who returns with positive bacteriology } \\
\text { following interruption of treatment for two months or } \\
\text { more }\end{array}$ \\
\hline Relapse & $\begin{array}{l}\text { A patient previously treated for TB, who has been } \\
\text { declared cured or treatment completed and is diagnosed } \\
\text { with positive bacteriology (smear or culture) } \\
\text { tuberculosis }\end{array}$ \\
\hline
\end{tabular}


Table2. Prevalence of Mycobacteria detected by ZN smear microscopy, LJ culture and IS 6110 PCR in HIV-positive patients.

\begin{tabular}{|c|c|c|c|c|c|c|}
\hline \multicolumn{7}{|c|}{ Number $(\%)$ detected } \\
\hline TB Cases & $\begin{array}{l}\text { Total No } \\
\text { examined }\end{array}$ & $\begin{array}{l}\text { ZNCCult" }^{-} \\
\text {PCR }^{-}\end{array}$ & $\begin{array}{l}\mathrm{ZN}^{+} \mathrm{Cult}^{+} \mathbf{P C} \\
\mathbf{R}^{+}\end{array}$ & $\begin{array}{l}\mathrm{ZNCCult}^{+} \\
\text {PCR }^{+}\end{array}$ & $\begin{array}{l}\text { ZNCCult }^{+} \\
\text {PCR }^{-}\end{array}$ & $\begin{array}{l}\begin{array}{l}\text { ZN }^{-} \text {Cult } \\
\text { PCR }^{+}\end{array}\end{array}$ \\
\hline New & 70 & $47(67)$ & $3(4.3)$ & $9(13)$ & $4(6)$ & $7(10)$ \\
\hline Follow-up & 14 & $5(35)$ & $2(14)$ & $3(21)$ & 0 & $4(29)$ \\
\hline Fail & 9 & 4(44) & $1(11)$ & $2(22)$ & 0 & $2(22)$ \\
\hline Re-treatment & 2 & 0 & & 0 & 0 & $2(100)$ \\
\hline Relapse & 6 & 0 & & $2(33)$ & 0 & $4(67)$ \\
\hline Total & 101 & $56(55)$ & $6(6)$ & $16(16)$ & 4(4) & $19(19)$ \\
\hline
\end{tabular}

\section{DNA amplification}

PCR was performed in a $50 \mu \mathrm{l}$ reaction volume comprised of $5 \mu \mathrm{l}$ PCR 10X buffer (Fermentas $\left.{ }^{\circledR}\right)$; $1 \mu \mathrm{l}, 10 \mathrm{mM}$ dNTPs (Fermentas $\left.{ }^{\circledR}\right) ; 0.5 \mu \mathrm{l}$ each of $10 \mu \mathrm{M}$ oligonucleotide primers $\mathrm{IS}_{1} 5^{\prime}$ 'CCTGCGAGCGTAGGCGTCGG-3' and $\mathrm{IS}_{2}$ ' 5'CTCGTCCAGCGCCGCTTCGG-3' (Whitefield Scientific ${ }^{\circledR}$ PTY LTD South Africa), 0.5 $\mu 1$ Taq DNA polymerase (Fermentas $\left.{ }^{\circledR}\right), 37 \mu 1$ Nuclease free water and $5 \mu \mathrm{l}$ extracted DNA. The total reaction mixture was submitted to 35 cycles of $94^{\circ} \mathrm{C}$ for 1.30 minutes; $68^{\circ} \mathrm{C}$ for 1.30 minutes; $72^{\circ} \mathrm{C}$ for 1.30 minutes; after $94^{\circ} \mathrm{C}, 5$ minutes initial denaturation; and final extension of $72^{\circ} \mathrm{C}$ for 10 minutes. Amplicons and 100 base pair (Fermentas $\left.{ }^{\circledR}\right)$ molecular markers were loaded in $2 \%$ agarose gel stained in ethidium bromide $10 \mathrm{mg} / \mathrm{ml}$ (Promega ${ }^{\circledR}$ ) with 6X loading dye (Fermentas $\left.{ }^{\circledR}\right)$ and electrophoresed at $80 \mathrm{~V}$ for one hour.

One hundred twenty-three base pair (bp) target DNA fragments specific for $M$. tuberculosis complex were viewed under ultraviolet illumination (Fig 1). An in-house M. tuberculosis strain was used as positive control.

\section{Results}

Mycobacterium species was detected in 45/101 (44.5\%) of the specimens from HIV positive patients with; $6 \% \mathrm{ZN}^{+}$culture ${ }^{+} \mathrm{PCR}^{+}, 4 \% \mathrm{ZN}^{-}$culture ${ }^{+} \mathrm{PCR}^{-}$, $16 \% \mathrm{ZN}^{-}$culture ${ }^{+} \mathrm{PCR}^{+}, 19 \% \mathrm{ZN}^{-}$culture ${ }^{-} \mathrm{PCR}$ and $39 / 45 \quad(86 \%) \quad \mathrm{ZN}$ undetected cases that were culture ${ }^{+} \mathrm{PCR}^{+}$or culture $\mathrm{PCR}^{+}$(Table 2 ).

The detection rate according to patients' $\mathrm{TB}$ cases showed the following results: new: $23 / 70$ (33\%); follow-up: 9/14 (64.3\%); relapse: $6 / 6$ (100\%); fail: $5 / 9(55.5 \%)$; and re-treatment: $2 / 2$ $(100 \%)$ (Table 2.)

PCR method detected 19\% extra cases that were not detected by LJ culture or smear microscopy while 4/100 (4\%) culture-positive cases were not detected by PCR (Table 2).
ZN smear microscopy had a low sensitivity of 23\% against $84 \%$ for PCR and detected 6/101 (6\%) cases (Tables 2, 3).

In the children, Mycobacteria was detected in a total of $22 / 40(55 \%)$ clinical specimens with $0 \%$ smear microscopy; 4/40 (10\%) culture ${ }^{+} \mathrm{PCR}^{+;}$and $18 / 40(45 \%)$ culture $\mathrm{PCR}^{+}$. Ten out of $10(100 \%)$ sputum specimens examined were positive with $4 / 10$ (40\%) $\mathrm{ZN}^{-}$culture ${ }^{+} \mathrm{PCR}^{+}$and $10 / 10 \mathrm{ZN}^{-}$culture ${ }^{-}$ $\operatorname{PCR}^{+}(100 \%)$ (Table 4). Other clinical specimens [Pleural effusion: 7/9 (78\%); Gastric juice 3/10 (27\%); and ascitic fluid: $2 / 5$ (40\%)] were positive by PCR only. Five of the CSF specimens were negative by all three methods (Table 4).

\section{Discussion}

Mycobacteria were detected in $44.55 \%$ of the HIV-positive patients in this study. The result is within $35-40 \%$ estimated range for TB in HIV patients in Nigeria [20-21]. The prevalence 22/31 (71\%) [10/31 (32\%) culture $\left.{ }^{+}, 12 / 31(39 \%) \mathrm{PCR}^{+}\right]$ from the follow up, failed, re-treatment and relapse cases in this study is relatively high and requires further examination for drug susceptibility to rule out the presence of drug resistant strains. Acquired drug resistance in M. tuberculosis may occur in HIV-positive patients receiving concomitant treatment with anti-tuberculosis and anti-retroviral drugs due to intestinal mal-absorption or drug interactions [22-24].

Four of 101 (4\%) LJ isolates were not detected by PCR (Table2). The isolates may be other mycobacteria species requiring the use of species specific primers for confirmation since the IS6110 sequence specifically targets the M. tuberculosis complex group [18,15]. Culture by LJ detected $16 \%$ more cases than the ZN smear microscopy. Although the procedure is cumbersome and slow, it is cheap and affordable for use in laboratories with the biosafety containments required for mycobacteria culture. 
Table 3. Sensitivity and specificity of PCR and ZN smear microscopy in HIV-positive patients

\section{Culture}

\begin{tabular}{|c|c|c|c|c|c|}
\hline \multirow{3}{*}{ PCR } & & Positive & Negative & Sensitivity & Specificity \\
\hline & Positive & 22 & 19 & $84 \%$ & $74 \%$ \\
\hline & Negative & 4 & 55 & & \\
\hline \multirow[t]{2}{*}{$\mathrm{ZN}$} & Positive & 6 & 0 & $23 \%$ & $100 \%$ \\
\hline & Negative & 20 & 74 & & \\
\hline
\end{tabular}

Figure 1. Agarose gel electrophoresis of IS6110 based Polymerase chain reaction for detection of M. tuberculosis from clinical specimens

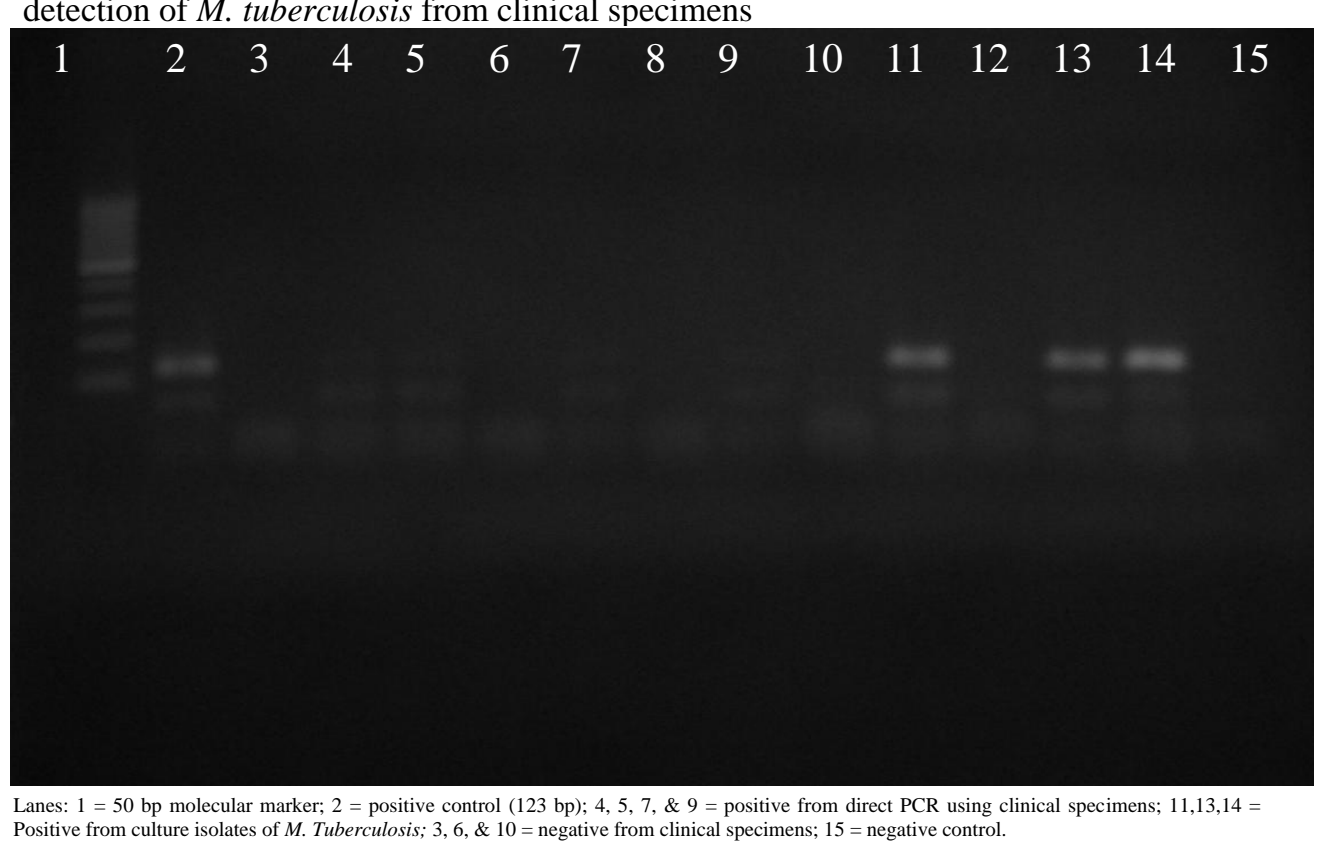

Table 4. The prevalence of Mycobacteria detected by ZN smear microscopy, LJ culture and IS 6110 PCR in clinical specimens of children N (\%)

\begin{tabular}{|llll|}
\hline Specimens & $\begin{array}{l}\text { Total No } \\
\text { Examined }\end{array}$ & Cult $^{+}$PCR $^{+}$ & Cult $^{+}$PCR $^{+}$ \\
Sputum & 10 & $4(40)$ & $6(60)$ \\
Gastric wash & 11 & 0 & $3(27)$ \\
CSF & 5 & 0 & 0 \\
Ascitic fluid & 5 & 0 & $2(40)$ \\
Pleural effusion & 9 & 0 & $7(78)$ \\
Total & $\mathbf{4 0}$ & $\mathbf{4 ( 1 0 )}$ & $\mathbf{1 8 ~ ( 4 5 )}$ \\
\hline
\end{tabular}

ZN = Ziehl Neelsen, Cult = Culture, PCR = Polymerase chain reaction

The detection of $6 / 101(6 \%)$ acid fast bacilli (AFB) with 39/101 (39\%) undetected cases which were otherwise culture/PCR positive (Table 2) calls for the improvement of TB diagnostic methods in Nigeria, particularly in HIV patients, because they are more likely to produce poor sputum quality. False negative TB cases constitute a risk to public health as long as they remain undetected and untreated.

In the children, mycobacteria was detected in a total of 22/40 (55\%) clinical specimens Four out of 
$10(40 \%)$ and 10/10 (100\%) sputum specimens were culture ${ }^{+} \mathrm{PCR}^{+}$and culture $\mathrm{PCR}^{+}$respectively (Table 4). Although sputum is considered most appropriate for laboratory diagnosis of PTB, children are often unable to expectorate sputum [25]. The possibilities of false negative results by conventional methods in this regard are high because other body fluids (gastric washout, pleural effusion and ascitic taps) used as alternatives [26] usually do not contain sufficient quantities of mycobacteria that could be detected by routine methods. Positive results 12/40 (75\%) were obtained for the clinical specimens other than sputum by PCR only (Table 4). The use of DNA PCR has been reported to improve the detection of Mycobacteria species in clinical specimens from children and adults [27-29].

In our experience, PCR increased the detection rate of $M$. tuberculosis but was cost intensive. It was estimated to cost about $\$ 15$ per test against $\$ 4$ for $\mathrm{LJ}$ culture and $\$ 2$ for smear microscopy at 110 Nigerian Naira to US \$1 exchange rate. In spite of the price differences, the sensitivity and short turn-around time of PCR outweighs its costs. While cost effectiveness and affordability are significant in the choice of diagnostic methods, especially in resourcelimited settings, the cost of losses in terms of life is much more expensive.

A common problem with PCR assays is the high risk of false positive results due to laboratory contamination or the presence of killed or dormant bacilli in the patient's specimen [30-31]. Proper control checks, good laboratory practice, and conformity of laboratory results with clinical findings would optimally minimise the chances of errors.

The overall low prevalence of $\mathrm{ZN}$ positive smear microscopy (4.2\%) in this study reflected the $31 \%$ actual sputum smear positive detection rate reported in Nigeria [9], which is less than the $70 \%$ global target recommended by the World Health Organisation [32].

We suggest that $\mathrm{TB}$ reference centres in countries such as Nigeria with high TB and HIV burdens should consider the use of PCR in combination with smear microscopy to enhance prompt detection of M. tuberculosis in HIV-positive patients, in children, and in other cases with low mycobacteria sputum content.

\section{Acknowledgements}

The JALMA Institute for Leprosy and other Mycobacterial Research, Tajganj Agra, kindly provided oligonucleotide primers used at the initial stage of the study. We thank the National Veterinary Research Institute (NVRI), Vom, for permitting the use of their molecular biology unit during this study. Staff members of the Department of Medical Microbiology, University of Jos and the APIN Laboratory, JUTH are duly acknowledged.

\section{References}

1. Raviglione MC, Narain, JP Kochi A (1992) HIV associated tuberculosis in developing countries. Clinical features, diagnosis and treatment. Bull World Health Organis, 70: 515-525.

2. Tortolli E and Palomino JC (2007) New diagnostic methods: In Tuberculosis: From basic science to patient care 441-186.

3. Mustapha AS, Abal AT, Chugh TD (1999) Detection of Mycobacterium tuberculosis complex and non tuberculosis mycobacteria by multiplex polymerase chain reaction. EMHJ 5: 61-70.

4. Elliott AM, Namaambo K, Allen BW, Luo N, Hayes R.J, Pobee JO, McAdam, K P (1993) Negative sputum smear results in HIV patients with positive pulmonary tuberculosis in Lusakka, Zambia. Tuber Lung Dis 74: 191194.

5. de Albuquerque Mde F, Alburqueque SC, Campelo AR, Cruz M, DE Souza WV, Ximenes RA, de Souza RA (2001) Radiographic features of pulmonary tuberculosis in patients infected by HIV: is there an objective indicator of coinfection? Rev Soc Bras Med Trop 34: 369-372.

6. World Health Organisation. Global tuberculosis controlsurveillance, planning and financing. WHO Report (2004).WHO/HTM/TB/2004331; http//www.who.int.th/publication/global report/en.

7. Kent PT, Kubica GP, Division of laboratory training and consultation. Laboratory Program Office. US department of health and human services PHS 1985 CDC Atlanta Georgia. 30333.

8. National tuberculosis and leprosy control programme (2007). Annual report. Federal ministry of health.

9. Hargneaves NJ, Kadzakumanga O, Whilty CJM, Salamiponi FML, Harries AD. Squire SB (2001) Smear negative pulmonary tuberculosis in a DOTS programme; poor outcome in an area of high HIV seroprevalence. Int $\mathrm{J}$ Lung Dis 5: 847-854.

10. World Health Organisation (2002) An expanded framework for effective tuberculosis control, Geneva. WHO/CDS/TB/2002.297.

11. Ani AE, Idoko J, Dalyop YB, Pitmang SL (1989) Drug resistance profile of Mycobactrium tuberculosis isolates from pulmonary tuberculosis patients in Jos, Nigeria. Trans Roy Soc Trop Med Hyg 103: 67-71.

12. Brisson-Noel A, Aznar C, Chureau C, Nguyen S, Pierre C, Bartoli M, Bonete R, Pialoux G, Gicquel B Garrigue G (1991) Diagnosis of tuberculosis by DNA amplification in clinical practice evaluation. Lancet 338: 346-366.

13. Walker DA, Taylor IK, Mitchell DM, Shaw RJ (1992) Comparison of polymerase chain reaction amplification of two mycobacterial DNA sequences, IS6110 and the $65 \mathrm{KDa}$ antigen gene in the diagnosis of tuberculosis. Thorax 47: 690-694. 
14. Pietrzak J, Frei R, Senn HP, Moroni C (1994) Polymerase chain reaction with standard methods in the diagnosis of tuberculosis in sputum. Eu J Clin Infect Dis 13:1079-1083.

15. Hellyer TJ, Des Jardin LE, Assaf MK, Bates JH, Cave MD Eisenach, K. D (1996). Specificity of IS6110 based amplification assays for Mycobacterium tuberculosis complex. J Clin Microbiol 34:2843-2846.

16. Torrea G, van de Perre P, Ouedraogo M, Zougba A, Sawadogo A, Dingtoumda B, Diallo B, Defer MC, Sombie I, Zanatti S, Sechi LA (2005) PCR based detection of Mycobacterium tuberculosis complex in urine of HIVinfected and uninfected pulmonary and extra pulmonary patients in Burkina Faso. J Med Microbiol 54: 39-44.

17. Kambashi BG, Mbulu R, McNerncy R, Tembwe A, Kambashi V, Tihon P Godfrey-Fausett (2001) Utility of nucleic acid amplification technique for the diagnosis of pulmonary tuberculosis in sub Saharan Africa. Int J Tuberc Lung Dis 5: 364-369.

18. Eisenach KD, Cave M D, Bats JH, Crawford JT (1990) Polymerase chain reaction amplification of a repetitive DNA sequence specific for Mycobacterium tuberulosis. J Infect Dis 161: 977-981.

19. Kien TE, Cammarata R (1986) Laboratory diagnosis of Mycobacterial infection in patients with acquired immunodeficiency disorder. J Clin Microbiol 26: 708-711.

20. Awoyemi OB, Ige OM, Onadeko BO (2002) Prevalence of pulmonary tuberculosis in human immunodeficiency virus seropositive adults in University Teaching Hospital, Ibadan, Nigeria. Afr J Med Sci 31: 329-332.

21. Salami AK, Katibi IA (2006) Human immunodeficiency virus-associated tuberculois: Pattern and trend in the University of Ilorin Teaching Hospital. W Afr J.Med 21: 24-27.

22. Sandman L, Schluger NW, Davidson AL, Bonk S (1991) Risk factors for rifampin-monoresistant tuberculosis. A case control study. Am J Respir Crit Care Med 159: 468472.

23. Campos PE, Suarez PG, Sanchez J, Zavala D, Arevalo J, Ticona, E, et al. (2003) Multidrug-resistant Mycobacterium tuberculosis in HIV-infected persons. Peru Emerg Infect Dis. 9: 1571-1578.

24. Aaron L, Saadoun D, Calatroni I, Launay O, Memain N, Vincent V, et al. (2004) Tuberculosis in HIV infected patients a comprehensive review. Clin Microbiol Infect 10: 388-398.
25. Starke JR and Taylor-Walts KT (1989) Tuberculosis in the paediatric population of Houston. Paediatr 84: 28-35.

26. Khan EA and Starke JR (1995) Diagnosis of tuberculosis in children: increased need for better methods. Emg Inf Dis 2: 115-123.

27. Cousins DV, Wilton SD, Francis BR, Brown BL (1992) Polymerase chain reaction for rapid diagnosis of tuberculosis. J Clin Microbiol 30: 255- 258.

28. Delacourt C, Poveda J, Chureau C, Beydon, Mahut B, Blic J, Scheiman P Garrigue G I (1995) Use of polymerase chain reaction for improved diagnosis of tuberculosis in children. J Paediar 126: 703-709.

29. Noorehoek GT, Kolk AH, Bjune G, Cathy D, Dale JW, Fine PE (1994) Sensitivity and specificity of polymerase chain reaction for the detection of Mycobacterium tuberculosis a blind comparison study among seven laboratories. J Clin Microbiol 32: 277-284.

30. Beige J, Lokies J, Schaberg T, Finckh M, Fischer M, Mauch H, Lode H, Kohler, B Rolfs A (1995) Clinical evaluation of a Mycobacterium tuberculosis PCR assay. J Clin Microbiol 33: 90-95.

31. Connelly Smith K, Starke JR, Eisenach K, Ong LT, Denby M (1996) Detection of Mycobacterium tuberculosis in clinical specimens from children using polymerase chain reaction . Paediatr 97: 155-160.

32. World Health Organisation (2003). Treatment of tuberculosis: Guidelines for national programs. WHO/CDS/TB/2003313.

\section{Corresponding author}

Dr. Agatha Ani

Department of Medical Microbiology

University of Jos, PMB 2084, Jos

and

Harvard APIN+ Jos University Teaching Hospital, Jos

Email: aniaek@yahoo.com

Tel +2348033578127

Conflict of interest: No conflict of interest is declared. 